International Journal of Trade $\mathcal{E}$ Commerce-IIARTC

January-June 2020, Volume 9, No. 1 pp. 200-212

(C) SGSR. (www.sgsrjournals.co.in) All rights reserved

Double Blind Peer Reviewed/Referred International Indexed Journal

ISRA JIF: 6.318; COSMOS (Germany) JIF: 5.135; ISI JIF: 3.721; NAAS Rating 3.55

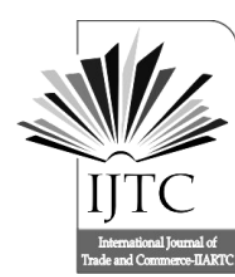

\title{
Marketing System of Plastic Door in Bangladesh: A Study on Aziz Pipes Limited
}

\author{
Md. Zahir Uddin Arif ${ }^{a *}$, Mohammad Amzad Hossain Sarker ${ }^{b}$ and Mir Semon \\ Haider $^{c}$ \\ a Department of Marketing, Faculty of Business Studies, Jagannath University, Dhaka-1100, Bangladesh \\ Email Id:mjarif2004@yahoo.com,mjarif2006@gmail.com \\ bDepartment of Marketing, Faculty of Business Studies, Comilla University, Kotbari, Cumilla-3506, Bangladesh \\ Email Id:emailtoamzad@yahoo.com,amzadbba@yahoo.com \\ c College of Business Administration, International University of Business, Agriculture and Technology (IUBAT), 4 \\ Embankment Drive Road, Sector-10, Uttara Model Town, Dhaka-1230, Bangladesh \\ Email Id: semonhaider77@gmail.com
}

\begin{abstract}
1. Purpose: The purpose of the study is to analyze the marketing system of plastic door of Aziz Pipes Limited in Bangladesh.

2. Design/methodology/approach: Exploratory research design has been used for the study. The study has collected data from primary and secondary sources. The study has obtained primary data from manufacturers, dealers, developers, architectural firms and individual consumers selected through purposive sampling technique. Opinions of the respondents about marketing system of plastic door have been gathered through face to face interview using separate sets of semi-structured (open-ended and closedended) questionnaires for each category of respondents. However, secondary data have been gathered and analyzed for the study from company annual reports, books, journals, and websites.

3. Findings: The findings of the study indicate about the existing marketing system and channels of distribution used, sources and kinds of raw materials, PVC profile manufacturing process, the pricing policy, opportunity and threat analysis and marketing functions faced by the company. There is a major limitation, especially in promotional efforts. Therefore, the company should take effective measures to create favorable brand image towards markets and attain relatively better performance of this industry following market driven strategy.

4. Practical implications: The study has practical implications for the manufacturers, dealers, developers, architectural firms, individual consumers, investors, policymakers, industry experts and media to discuss and create a sustainable marketing practice for plastic door in Bangladesh.

5. Originality/value: The study will help to originate the value to the manufacturers, dealers, developers, architectural firms and individual consumers of plastic door if the effective and efficient marketing system can be practiced more rigorously for better proliferation of the segmented markets. As a result, marketers can incorporate the convenient marketing mix structure in order to provide an insight for the plastic door industry in Bangladesh to evaluate the effectiveness of their marketing strategies and tactics.

Key Words: Channels of distribution, Market information, Marketing mix, Marketing system, Plastic door, PVC profile.
\end{abstract}

PAPER/ARTICLE INFO RECEIVED ON: 22/04/2020 ACCEPTED ON: 15/06/2020

Reference to this paper should be made as follows:

Md. Zahir Uddin Arif, Mohammad Amzad Hossain Sarker and Mir Semon Haider (2020), "Marketing System of Plastic Door in Bangladesh: A Study on Aziz Pipes Limited", Int. J. of Trade and Commerce-IIARTC, Vol. 9, No. 1 , pp. $200-212$ 


\section{INTRODUCTION}

Aziz Pipes Limited has been incorporated in 1981 in Bangladesh to manufacture PVC rigid pipes and has started its commercial production in 1985 with the yearly installed capacity of 1,200 metric tons. With the passage of 12 years from 1985 to 1996, the company has increased its total production capacity of 7,500 metric tons. In 1995, the company diversified its production line of manufacturing PVC flexible corrugated conduit pipes. Aziz Pipes Limited is a pioneer in the plastic door production of Bangladesh (http://www.azizpipes.com/about-us/). The company started its plastic door production in 1998. After that, United Plastic Wood Industries (Pvt.) Limited introduced a plastic door in the market in 2000. Besides this, Super Door, Prime Plastic Door, Alam Plastic Door, Premier Plastic Door, Euro-Asia Multipurpose Profile Limited, etc. also have started to produce the plastic door in Bangladesh. PVC (Polyvinyl chloride) profile means different sections and sizes of pieces, which are used as the main components for making doors and windows for the house and office decoration, exhibition stand construction, shop fittings, dividing walls, working tables, etc. But this is one of the innovative products in Bangladesh instead of wooden made furniture. In recent years, people's views have been changed toward the use of plastic doors, windows, and related furniture. Competition among different plastic door producing companies has also been increased at a faster rate, but this sector is one of the least research sectors in Bangladesh. Minimal studies have been conducted earlier in the plastic door industry of the country. Therefore, the present research on the marketing system of the plastic door of Aziz Pipes Limited is an attempt to fill this gap.

\section{Conceptual Definition and Literature Review}

PVC stands for polyvinyl chloride, which is a synthetic resin prepared by the polymerization of vinyl chloride (http://wiki.answers.com/Q/What_does_PVC_stand_for_in_PVC_pipe\#ixzz2CTj6Jw92). PVC (Polyvinyl chloride) is used extensively in sewage pipe due to its low cost, ease of jointing, and chemical resistance. In the world, PVC is the third-most widely manufactured plastic after polyethylene and polypropylene. (http://www.americanchemistry.com/Jobs/EconomicStatistics/ Plastics-Statistics/Production-and-Sales-Data-by-Resin.pdf). PVC can be produced softer and more flexible by the addition of plasticizers, the most commonly used being phthalates. It is widely utilized in construction because it is more durable and cheaper than more traditional alternatives such as copper or ductile iron. In this form, PVC is used in electrical cable insulation, clothing and upholstery, inflatable products, and many other applications in which it replaces rubber (Titow, 1984). Pure polyvinyl chloride without the addition of any plasticizer is a white and brittle solid. It is insoluble in alcohol, but soluble slightly in tetrahydrofuran (http://en.wikipedia.org/wiki /Polyvinyl_chloride).

Marketing can be defined as a broad term, and it includes all resources and a set of functions necessary to direct and facilitate the flow of products and services from producer to consumer in the process of distribution (Sherlekar, 1997:4). According to Kotler (2002: 9), marketing is a societal procedure by which individuals and groups people acquire what they need and want through making, offering, and freely exchanging goods and services of significant value with others.

The American Marketing Association (1995) has portrayed marketing as the route toward arranging and executing the origination, valuing, advancement, and dissemination of thoughts, merchandise, and services to make exchanges that fulfill individual and institutional objectives. Paul Mazur has also characterized marketing as the creation and conveyance (delivery) of a standard of living to society. It underscores the significant function of marketing viz., the satisfaction of the client, and the social demand for material goods and services (Sherlekar, 1997:5). 
Modern marketing system utilizes the marketing mix which is the blending of 4Ps model (product, price, place, and promotion) developed by McCarthy and it controls among all other classifications, e.g., the goods and services mix, the distribution mix and the promotion mix (Lazer et al., 1973). The elements of the marketing mix seem to cover with each other when used as an integral part of the interrelated way of marketing activities, yet it is to be essential for product marketing (Dickson and Ginter, 1987; Rafiq and Ahmed, 1995).

Product is anything that can be offered to a market (a set of actual and potential buyers) for consideration, procurement, use, or utilization that can fulfill a need or want of a customer (Kotler and Armstrong, 2006).

Price is considered as better value to the customers in the general circumstances since low price presumably pulls in customers (Fleischmann et al., 2004).

Place or distribution indicates the placement of products by which the customers can buy the product and the product contacts that place through various channels, like dealers, wholesalers, retailers, and the internet (Booms and Bitner, 1981). The place also includes company functions or activities that make the product accessible to its target customers (Kotler and Armstrong, 2006).

Promotion indicates the activities which convey the benefits or utilities of the product and allure target customers to purchase it (Kotler and Armstrong, 2006: 50). Promotion consists of a particular mix of advertising, sales promotion, personal selling, and public relations (Kotler and Keller, 2006).

Khan (2003) has revealed the production and sales pattern of plastic doors, purchasing pattern of private users \& apartment companies, dealers' \& architects' opinions and impressions regarding plastic doors, and increasing demands of plastic doors day by day in his study.

As the UPVC windows (un-plasticized polyvinyl chloride windows) are the new entrance to the Indian market, there have no significant studies conducted in India. Improvement of product quality is one of the critical product-related marketing strategies in the doors and windows market of India. Advertisements to increase the brand image and exhibitions are the two crucial promotional strategies that influence the consumers in their purchase decision of plastic doors and windows. However, price and timely service are also the two more important factors that need to be focused (Subram, 2018).

There are very few scholarly articles published on the marketing aspects of the plastic doors of Bangladeshi companies. As an innovative product in Bangladesh, more competition among various plastic door manufacturing companies is growing day by day. So there is a potentiality to conduct more systematic studies in the marketing aspects of the plastic door in Bangladesh. As a result, the present research on the marketing system of the plastic door of Aziz Pipes Limited has been conducted to fill up this research gap in the context of Bangladesh.

\section{OBJeCTIVES OF THE STUDY}

The broad objective of the study is to analyze the marketing system of the plastic door of Aziz Pipes Limited in Bangladesh. To optimize the general aim of the study, the specific goals are as follows:

i. To determine the marketing system of the plastic door of Aziz Pipes Limited and the channels of distribution used for the purpose.

ii. To identify the marketing functions which are performed in plastic door marketing by Aziz Pipes Limited.

iii. To find out the problems (if any) which are faced by Aziz Pipes Limited in the marketing of its plastic door.

iv. To recommend measures for improving the present marketing system of the plastic door of Aziz Pipes Limited. 
Marketing System of Plastic Door in Bangladesh: A Study on Aziz Pipes Limited

Md. Zahir Uddin Arif, Mohammad Amzad Hossain Sarker and Mir Semon Haider

\section{The Methodology OF THE Study}

Exploratory research design has been used for the study. To attain the objectives, the study has been confined to analyze the marketing system of the plastic door of Aziz Pipes Limited in Bangladesh, and relevant data \& information has been collected from previous records of the company and the responsible personnel concerned of the company. Primary data have been collected from the executives of Aziz Pipes Limited with the help of a semi-structured (openended and closed-ended) questionnaire prepared beforehand for the purpose. Similarly, an attempt has been made to draw a sample from as diversified groups as possible to make the survey representative. To supplement the information, the discussions have been made with the executives of different plastic door manufacturing companies such as United Plastic Wood Industries Limited, Super Door, Prime Plastic Door, Alam Plastic Door, Premier Plastic Door, Euro-Asia Multipurpose Profile Limited, etc. Besides, 25 dealers of Aziz Pipes Limited, ten developers, ten architectural firms, and 55 individual consumers have been selected purposively. They have been interviewed with the help of separate sets of semi-structured questionnaires for each category of respondents. As a sampling frame, Yellow Pages, a business directory published in Dhaka, Bangladesh, has been used to extract the names of manufacturers, developers, and architectural firms, and the names of dealers have been collected from the sales department of Aziz Pipes Limited. However, secondary data have been gathered and analyzed for the study from the annual reports of Aziz Pipes Limited (2016, 2017, and 2018), books, journals, and websites. The data and information have been analyzed in the narrative form and also presented in the table and diagram. The data redundancy has been avoided after cross-checking, cleaning, and compilation of the data necessary for the study.

\section{FINDINGS AND ANALYSIS OF THE STUDY}

The study has revealed the following information:

5.1. The Product: The brand name of the product of Aziz Pipes Limited is 'Aziz Plastic Door.' Theoretically, the product is a set of benefits that the companies offer to customers to satisfy their needs or wants (Kotler, 2002). In other words, the product is the solution to any problem felt by any customer. In this study, it has been found that plastic door has the different title of sections which include door sash, sliding frames, sliding sash, sliding interlock, sliding coupling, partition frame and mullion (shown in Appendix-II). However, this plastic door consists of some features, which include excellent fire retardant, excellent weather-resistant, superior soundproofing, corrosion-resistant, excellent thermal efficiency, and electricity insulated.

Properties of profiles are impervious to insects, optimum surface finishes, strong and durable, low-density corresponding to very lightweight, easily nailable and screwable, easy to cut with a saw, resistant to scratches from regular use, and quickly bonded to another material set, etc. After attaching the profiles with PVC sheets, the finished products will be used in the making-

i. $\quad$ Doors and windows for home and office decoration.

ii. Exhibition stand construction, shop fittings, dividing walls.

iii. Bathroom and kitchen furniture shelves, coup boards, false ceilings.

iv. Containers and tank liners, working tables, cover-sheets, etc.

The company produces a standard size PVC profile, which is usually 10-12 feet. Aziz Pipes Limited has the highest market share (35\%) and the lowest market share gained by Euro-Asia Multipurpose Profile Limited (7\%).

The assembling/manufacturing process followed by the company is stated below:

At the first stage of production, it is needed to supply raw materials. The primary raw material is PVC resin; others are stabilizer, filler calcium carbonate, and so on. In this process, different steps pass through weighing equipment, heating mixture, cooling mixture, and so on. Finally, after inspection, successful products are packed, and wastage products are crushed. The following Diagram-1 shows the different stages of production of the PVC profile (PVC profile manufacturing process). 
Marketing System of Plastic Door in Bangladesh: A Study on Aziz Pipes Limited Md. Zahir Uddin Arif, Mohammad Amzad Hossain Sarker and Mir Semon Haider

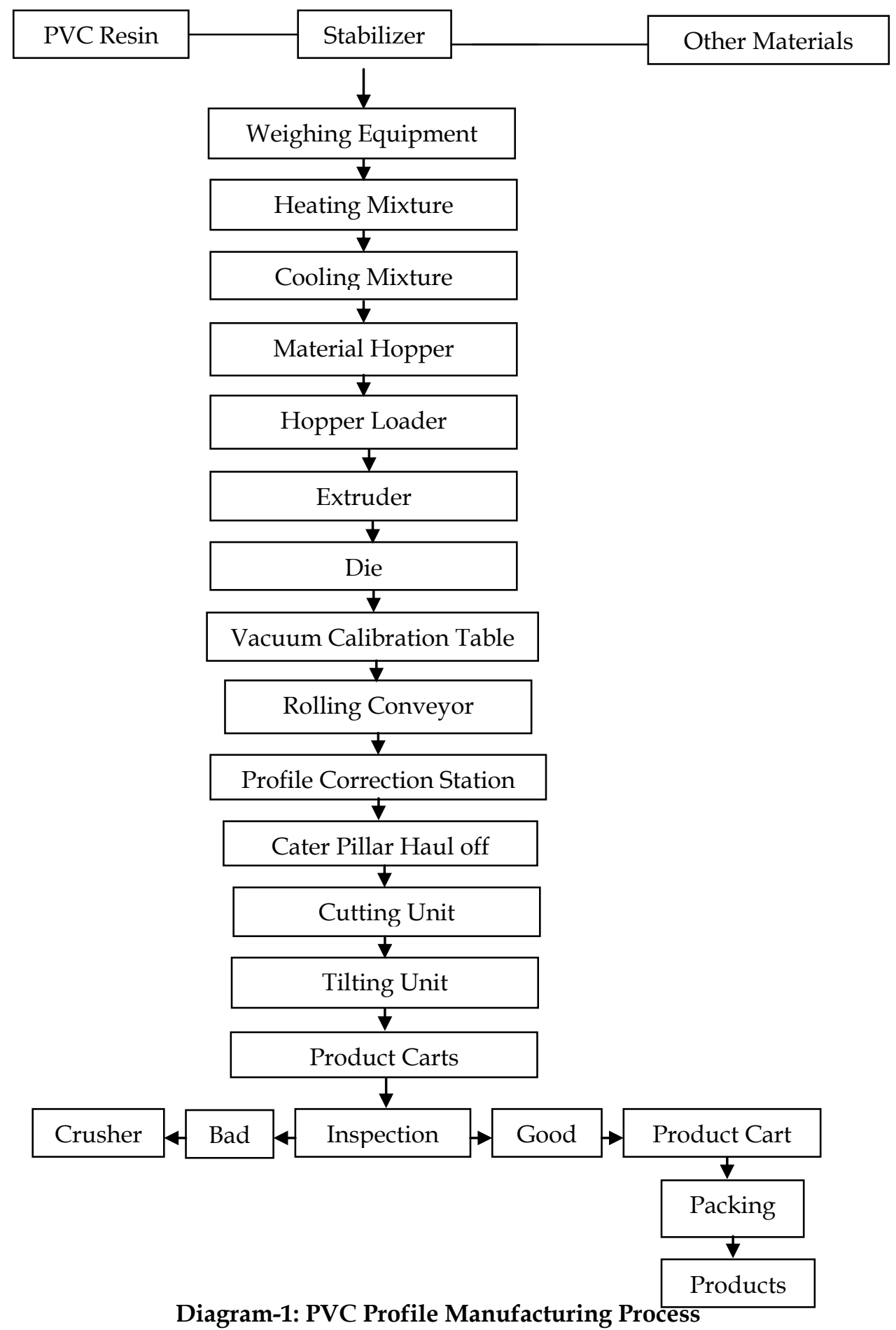

Source: Aziz Pipes Limited

Diagram-1: PVC Profile Manufacturing Process

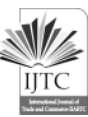


5.2. Raw Materials: All raw materials are imported from abroad, such as China, India, Austria, France, Singapore, etc. on a cash basis against L/C. Raw materials used in producing profiles are resin (original content), stabilizer, filler calcium carbonate, import modifier (for strength), etc. The color used in producing patterns is delirium oxide for white color, pigment gray for gray color, pigment pitch for wooden color.

In the production process, overall functions are very much interdependent. In the following Table-1, it is found that input (raw materials) of one stage is transferred to another step as output (powder mix). This output (powder mix) is treated as an input for another level, and so on. Thus, the following Table- 1 shows machinery and its functions in producing PVC profile:

Table-1: Machinery and Its Functions in Producing PVC Profile

\begin{tabular}{|c|c|c|c|c|c|}
\hline $\begin{array}{l}\text { Sl. } \\
\text { No. }\end{array}$ & Name of Machine & Origin & Function & Input & Output \\
\hline 1. & $\begin{array}{l}\text { Mixture Machine } \\
\text { NEOPLAST }\end{array}$ & India & $\begin{array}{l}\text { The function of this machine is to } \\
\text { mix up the raw materials with } \\
\text { color. }\end{array}$ & $\begin{array}{l}\text { Raw } \\
\text { Materials }\end{array}$ & $\begin{array}{l}\text { Powder } \\
\text { Mixture }\end{array}$ \\
\hline 2. & $\begin{array}{l}\text { Actual Type: TITA N-45-P } \\
\text { M-15-7157 }\end{array}$ & Austria & $\begin{array}{l}\text { Here mixture powder is again } \\
\text { mixed up and then is cooled down } \\
\text { with the help of sufficient water. }\end{array}$ & $\begin{array}{l}\text { Powder } \\
\text { Mixture }\end{array}$ & Pulp \\
\hline 3. & $\begin{array}{l}\text { Actual-First Cooling } \\
\text { Machine } \\
\text { Type: AKT-321-M-15-7658 } \\
\text { Second Cooling Machine }\end{array}$ & Austria & $\begin{array}{l}\text { The first cooling machine helps to } \\
\text { cool the profile through cold } \\
\text { water. The second cooling machine } \\
\text { helps to calm the pattern only. }\end{array}$ & Pulp & $\begin{array}{l}\text { Shape of } \\
\text { Profile }\end{array}$ \\
\hline 4. & $\begin{array}{l}\text { Take-up/Haul off } \\
\text { Machine } \\
\text { Type: AP*-2000 } \\
\text { M-15-7660 }\end{array}$ & Austria & $\begin{array}{l}\text { Take-up/Haul off machine helps } \\
\text { to pull the profile. It has a padded } \\
\text { rubber around its body. }\end{array}$ & $\begin{array}{l}\text { Shape of } \\
\text { Profile }\end{array}$ & $\begin{array}{l}\text { Final } \\
\text { Profile }\end{array}$ \\
\hline 5. & $\begin{array}{l}\text { Cutter Machine } \\
\text { Type: APS-400 } \\
\text { M-15-7661 }\end{array}$ & Austria & $\begin{array}{l}\text { Cutter machine helps to cut the } \\
\text { profile in a specified limit switch. }\end{array}$ & $\begin{array}{l}\text { Final } \\
\text { Profile }\end{array}$ & $\begin{array}{l}10-12 \\
\text { feet } \\
\text { Profile } \\
\end{array}$ \\
\hline
\end{tabular}

Source: Aziz Pipes Limited

5.3. The channel of Distribution: Aziz Pipes Limited uses only 'dealers' as a member of the chain of distribution. This is because the buyers usually visit different dealers' showrooms and choose a particular profile for making a complete useable door. The dealers procure the entries directly from the manufacturers and sell this to the customers regarding the mode of payment by the dealers, usually on cash. During this payment, dealers get a 10\% cash discount. Aziz Pipes Limited uses the following channel of distribution (Diagram-2) for its products:

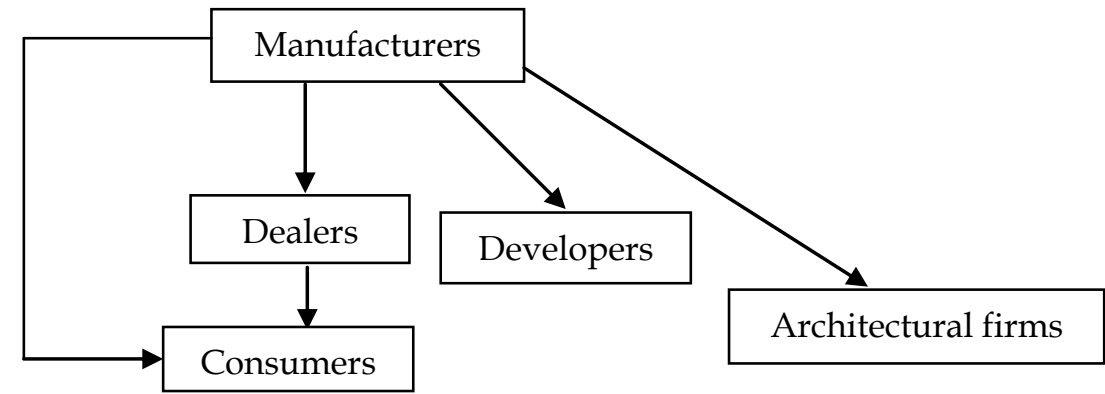

Diagram-2: Channel of Distribution of Aziz Pipes Limited

Source: Aziz Pipes Limited 
5.3.1. The manufacturer: As a manufacturer, Aziz Pipes Limited distributes its products through the legal dealers. Dealers are selected based on trial and error, and in the process, those dealers are chosen who can attain a higher volume of sales and are useful in payment. However, Aziz Pipes Limited also sells the products directly to individual consumers, developers, and architectural firms.

Aziz Pipes Limited supplies the products mainly to Dhaka Stadium Market, Outer Stadium Market, Old Dhaka, Panthapath Road, Kawranbazar Road, Mailbag Market, and about $60 \%$ of the products produced by the company are marketed in Dhaka city alone. Since the manufacturer has no vehicle of its own to deliver the products, the dealers themselves take the responsibilities of the delivery of these products from the manufacturer.

5.3.2. The dealer: At present, Aziz Pipes Limited has 25 dealers all over the country. Out of these, seven dealers are located in Dhaka city alone, and the rest 18 dealers are located in different districts of Bangladesh.

5.3.3. The consumer/user: Developers and architectural firms are the primary user of plastic doors and windows. Individual consumers often purchase these products for their use. The users (the respondents) expressed that the gates of Aziz Pipes Limited are relatively cheaper; properties are acceptable, quality is better, and they are satisfied with the company's aftersale service.

5.4. Marketing Functions: The following functions are involved in the marketing of plastic doors of Aziz Pipes Limited:

5.4.1. Buying/procurement: All raw materials and machinery are purchased from abroad. To import raw materials and machinery (parts and components), Aziz Pipes Limited first of all procure samples through indent. The quality of the sample is then tested in the quality control department of the factory. After the approval of the quality control department, consideration of different terms and conditions, and permission by the production and marketing department and sanction by the finance department, the initiative is taken for import of required items (Raw materials and machinery) through the opening of $\mathrm{L} / \mathrm{C}$ in the bank.

5.4.2. Selling: Aziz Pipes Limited sells its finished products to dealers and the ultimate users. After production, products are stored at factory godown and distributed to dealers by given order from them. It also delivers products directly to developers and architectural firms according to their requirements. The prices of different sizes of doors (with profile) are given in the following Table-2:

Table-2: Prices of Different Sizes of Doors (with Profile) of Aziz Pipes Limited

\begin{tabular}{|c|c|c|}
\hline Color of Door & $\begin{array}{c}\text { Size of Door } \\
\text { (Width X Length) }\end{array}$ & $\begin{array}{c}\text { Price of Door (BDT approx.) } \\
\text { Per Piece }\end{array}$ \\
\hline \multirow{3}{*}{ Wooden } & $3^{\prime} 5^{\prime \prime} \times 6^{\prime}$ & 2800 \\
& $3^{\prime} 5^{\prime \prime} \times 6^{\prime \prime}$ & 3500 \\
& $3^{\prime} \times 6^{\prime}$ & 2500 \\
\hline \multirow{3}{*}{ White } & $3^{\prime} 5^{\prime \prime} \times 6^{\prime}$ & 2500 \\
& $3^{\prime} 5^{\prime \prime} \times 6^{\prime} 5^{\prime \prime}$ & 3000 \\
& $3^{\prime} \times 6^{\prime}$ & 2200 \\
\hline \multirow{2}{*}{ Grey } & $3^{\prime} 5^{\prime \prime} \times 6^{\prime}$ & 2600 \\
& $3^{\prime} 5^{\prime \prime} \times 6^{\prime} 5^{\prime \prime}$ & 3200 \\
& $3^{\prime} \times 6^{\prime}$ & 2300 \\
\hline
\end{tabular}

Source: Aziz Pipes Limited 
5.4.3. Transportation: Aziz Pipes Limited has a limited transport facility for distributing its products. Hence, the dealers arrange transport for themselves. The dealers outside Dhaka city use any type of vehicle as they like. Nevertheless, trucks are the most convenient vehicles used by the dealers.

5.4.4. Warehousing: Aziz Pipes Limited uses its godown for storing the products. Storage is done at the following functions:

a. The imported raw materials are stored at the factory godown.

b. The finished products are stored at the factory godown.

c. Finally, the stored products are delivered to the dealers according to their order.

The warehousing arrangement of the factory is satisfactory, and therefore, no damage of the products occurs there. Besides, storing the finished products at its godown involves almost no cost.

5.4.5. Standardization and grading: Quality control of PVC profile and sheet, which are the elements of making of the plastic door is done with the help of most modern machinery under the supervision of skilled professional engineers. There are three categories of production extruder (shown in appendix-I) Shift-A, Shift-B, and Shift-C. Quality control of 'A' shift operation is done with the help of different types of machinery such as Cylinder, Adapter, Die, Vent. V. Pump, and so on. For this purpose, test results about quality must be certified by the production manager.

5.4.6. Packing and labeling: Aziz Pipes Limited procures necessary packing materials from a local supplier. It supplies plastic packing materials according to the standard profile or sheet size. It also uses labels on packed product items.

5.4.7. Advertising and sales promotion: In marketing the products, Aziz Pipes Limited did not follow the proper methods and techniques of advertising. It uses the only signboard, which is hoarding on roadsides, essential buildings, and stickers on important office doors, traveling office gates, etc. as promotional tools. For sales promotion, the company participates in different trade fairs and exhibitions. The company prefers personal contact with developers and architectural firms for better sales. It also gives various incentives to dealers for more deals to individual consumers.

5.4.8. Market information: Aziz Pipes Limited collects information about the market through individual buyers, dealers, developers, and architectural firms located in different towns and cities of Bangladesh. The company always keenly observes prices, quality, demand, sales rate, promotional program, etc. followed by its competitors.

5.4.9. Risk-taking: To face a particular risk in the shipment of imported raw materials from abroad, the company undertakes insurance policies.

5.5. Pricing Policy: The most simple pricing method is to add a standard markup to the cost of a product. The price of the PVC profile depends on different sections and sizes. Generally1012 feet profiles are available at the dealers. The company follows two pricing methods to sell their finished products. One is product costs that set a floor to the price, and another is competitor's prices and the price of substitutes, which provide an orienting point that the company has to consider in setting its prices.

5.6. Opinions of Manufacturer, Dealers, Architectural Firms, and Consumers: Opinions have been obtained from the dealers, the consumers/users, and the relevant executives of developers and architectural firms regarding the quality, price, most demandable color, 
sales and mode of purchase. The company renders the attitudes of customers, prospects, promotional efforts, and services. A comparative analysis of these is given below:

5.6.1. Quality of the product: The manufacturer has considered that the quality of its product is satisfactory. Most of the dealers (the respondents) have expressed positive attitudes about the quality of the product. The majority of respondents $(80 \%)$ of the consumers (individual, developers, and architectural firms) have considered that the quality of the product is up to the mark. In contrast, the rest have thought that its performance is entirely satisfactory.

5.6.2. Price: The general dealers have opined that the cost of the plastic door and door frame may fluctuate due to change in market conditions, competition, prices of raw materials, etc. The majority of respondents $(75 \%)$ of the consumers believe that the prices of the products are quite reasonable while the rest consider that the costs of the plastic doors of different sizes and colors are higher compared to their competitors, especially in wooden color doors. But the management of Aziz Pipes Limited has considered that the prices of products are competitive and reasonable.

5.6.3. Promotional efforts: Aziz Pipes Limited uses its dealers and maintains a relationship with the developers and architectural firms. The majority (about $80 \%$ ) of the individual consumers have opined that the company should increase the volume and quality of advertising as a promotional tool to make it more frequent and imaginative. The dealers have also emphasized on promotional efforts given the competition in the market. But the company has a limited budget for allocation for promotional programs.

5.6.4. Opportunities and Threats Analysis: Opportunities and threats of Aziz Pipes Limited are shown in the following Table-3:

Table-3: Opportunities and Threats of Aziz Pipes Limited Identified for the Study

\begin{tabular}{|l|rl|}
\hline \multicolumn{1}{|c|}{ Opportunities } & \multicolumn{1}{c|}{ Threats } \\
\hline i. $\quad \begin{array}{l}\text { PVC profile is non-corrosive and } \\
\text { entirely weather resistant. }\end{array}$ & i. $\begin{array}{l}\text { There is a negative attitude about the use of } \\
\text { plastic doors because people think that it is } \\
\text { harmful to health. }\end{array}$ \\
ii. It is easy to clean, and it can be used \\
$\begin{array}{l}\text { with or without a coating of paint or } \\
\text { varnish. }\end{array}$ & ii. $\begin{array}{l}\text { If suddenly scratch is made on the PVC } \\
\text { profile, this scratch is not possible to } \\
\text { remove. }\end{array}$ \\
$\begin{array}{l}\text { iii. It can also be planned, drilled, and } \\
\text { sawn, just like profile. }\end{array}$ & iii. $\begin{array}{l}\text { After a certain period, the PVC profile may } \\
\text { be disconnected from each other. }\end{array}$ \\
iv. It also absorbs sound and has very \\
lightweight.
\end{tabular}

Source: Authors' Compilation from Primary data

\section{Marketing Problems Identified From The StUdy}

The study revealed the following problems that are hampering the efficient marketing of plastic door produced by Aziz Pipes Limited:

i. Almost entire raw materials are imported from different countries of the world, such as China, India, Austria, France, Singapore, etc. Hence, delay in shipment or supply of raw materials hampers production for which the company cannot supply the products in time to its customers. 
ii. Due to budgetary limitations, the company did not use enough promotional tools. Notably, only advertising is not useful to fulfill the requirement compared to those of most of the competitors.

iii. In financing, the company depends mainly on bank loans. So, a shortage of capital hampers marketing functions.

iv. Due to the absence of a continuation of customer demand, the company cannot fully utilize the installed capacity.

v. The shortage of dealers is the prime problem of the proper distribution of products all over the country.

Besides the above, the company also has a problem with the shortage of efficient laborers. Insufficient electric supply also hampers its production and increases its wastage product. However, the lack of own transport facilities creates a significant problem in the distribution of products to the dealers.

\section{RECOMMENDATIONS}

As measures to increase the present efficiency of marketing of plastic door manufactured by Aziz Pipes Limited, the following suggestions can be recommended:

i. The company should run a promotional campaign to make the people aware of the usefulness of the plastic door and inform them about its benefits.

ii. The company should take the necessary steps to make a long-term marketing plan to capture significant market share.

iii. Manufacturers can improve market performance through improving product quality and reliability, ensuring the regularity of supply, ensuring the health and safety of consumers, and protecting the environment.

iv. The company should expand its distribution channel by increasing the number of dealers and by providing more credit facilities to them.

v. The company should take the necessary steps to build good relationships with developers and architectural firms.

\section{CONCLUSION}

The study has identified some problems in marketing of the plastic door of Aziz Pipes Limited in Bangladesh that is related to the whole process of marketing such as buying (procurement), selling, transportation, warehousing, quality control, advertising, packing, collection of market information, etc. But the main problem is revealed that the maximum number of people in Bangladesh do not know about the benefits of the plastic door. Because of the users' illiteracy, the producer is getting a chance to exploit them. Hence, the company needs to take steps to import better quality raw materials, reduce the cost of production, take effective promotional programs, expand the channel of distribution, and improve power (electricity) supply. To achieve these goals, the company may be granted the required freedom of decision-making in the financial, managerial, and promotional efforts. The government should take the necessary steps to improve the infrastructure of the plastic door industry in Bangladesh. From this study, it has been realized that there is a lot of opportunities for manufactures to expand its business in the plastic door industry of Bangladesh. However, there is a scope for conducting more qualitative and quantitative researches in the future by interested researchers in this field of study. 


\section{REFERENCES}

[1]. Aziz Pipes Limited. Annual Report, 2016, 2017, and 2018.

[2]. Booms, B. H., and Bitner M. J. (1981). Marketing Strategies and Organization Structures for Service Firms. In Donnelly, J. H., and George W. R. (eds.), Marketing of Services, Conference Proceedings: American Marketing Association, Chicago, IL, 47-52.

[3]. Dickson, P. R., and Ginter, J. L. (1987). Marketing Segmentation, Product Differentiation, and Marketing Strategy. Journal of Marketing, 51(2), 1-10.

[4]. Fleischmann, M., Hall, J. M. and Pyke, D. F. (2004). Smart Pricing. MIT Sloan Management Review, 45(2), 9-13.

[5]. http://en.wikipedia.org/wiki/Polyvinyl_chloride accessed on October 14, 2019.

[6]. http://wiki.answers.com/Q/What_does_PVC_stand_for_in_PVC_pipe\#ixzz2CTj6Jw92 accessed on October 20, 2019.

[7]. http://www.americanchemistry.com/Jobs/EconomicStatistics/PlasticsStatistics/Production-and-Sales-Data-by-Resin.pdf accessed on October 16, 2019.

[8]. http://www.azizpipes.com/about-us/ accessed on October 12, 2019.

[9]. Khan, E. A. (2003). Market Potentiality of Plastic Door in Bangladesh. Dhaka University Journal of Marketing, 6, 95-101. Available at SSRN: https://ssrn.com/abstract=1711039, accessed on October 17, 2019.

[10]. Kotler, P. (2002). Marketing Management, 11 th Edition, Forty-seventh Indian Reprint, Prentice-Hall of India Private Limited, New Delhi, July 9.

[11]. Kotler, P., and Armstrong, G. (2006). Principles of Marketing, 11th ed., Prentice-Hall, India.

[12]. Kotler, P., and Keller, K. (2006). Marketing Management, 12th ed., Prentice-Hall, Englewood Cliffs, NJ.

[13]. Lazer, W., Culley, J. D., and Staudt, T. (1973). The Concept of the Marketing Mix, in Britt, S. H. (ed.), Marketing Manager's Handbook, The Dartnell Corporation, Chicago, IL.

[14]. Rafiq, M., and Ahmed, P. K. (1995). Using the 7Ps as a Generic Marketing mix: An Exploratory Survey of UK and European Marketing Academics. Marketing Intelligence \& Planning, 13(9), 4-15.

[15]. Sherlekar, S. A. (1997). Marketing Management, 12 ${ }^{\text {th }}$ Revised and Enlarged Edition (Reprint), Himalaya Publishing House, Mumbai, 4-5.

[16]. Subram, K. S. (2018). A Study of the Marketing Mix strategies on the Indian UPVC Doors and Window Market, presented in International Conference on Marketing Strategies in Globalized Economic ERA Perspectives \& Challenges at Hyderabad, July.

[17]. The American Marketing Association (1995). Dictionary of Marketing Terms, $2^{\text {nd }}$ Edition, ed. Peter D. Bennett, Chicago.

[18]. Titow, W. V. (1984). PVC Technology, Springer, 6, December 31, ISBN 978-0-85334-249-6. http:/ / books.google.com.bd/books?id=N79YwkVx4kwC\&pg=PA6\&redir_esc=y\#v=onepa ge\&q\&f=false accessed on October 20, 2019. 
Marketing System of Plastic Door in Bangladesh: A Study on Aziz Pipes Limited Md. Zahir Uddin Arif, Mohammad Amzad Hossain Sarker and Mir Semon Haider

\section{APPENDICES}

\begin{tabular}{|c|c|c|c|}
\hline Machine & A Shift & B Shift & C Shift \\
\hline Syn \% & $65 \%$ & $65 \%$ & $60 \%$ \\
\hline Screw \% & 22.7 & 22.0 & 21.7 \\
\hline Feeder $\%$ & $10.8 \%$ & $10.1 \%$ & $10.0 \%$ \\
\hline Load \% & 78 & 75 & 70 \\
\hline Screw Tempo & 155 c.g & 152 c.g & 150 c.g. \\
\hline Cylinder-1 & 195 c.g & 192 c.g & 190 c.g. \\
\hline Cylinder-2 & 198 c.g & 195 c.g & 192 c.g \\
\hline Cylinder-3 & 190 c.g & 188 c.g & 185 c.g \\
\hline Cylinder-4 & 198 c.g & 195 c.g & 190 c.g \\
\hline Adapter & 185 c.g & 182 c.g & 180 c.g \\
\hline Die-1 & 195 c.g & 192 c.g & 190 c.g \\
\hline Die-2 & 200 c.g & 195 c.g & 190 c.g \\
\hline Die-3 & 200 c.g & 195 c.g & 195 c.g \\
\hline Die-4 & 225 c.g & 200 c.g & 200 c.g \\
\hline Vent. V. Pump & 600 & 550 & 500 \\
\hline Manf. Off Speed & 1.88 & 1.85 & 1.80 \\
\hline Manf. Off Load & 4.9 & 4.5 & 4.0 \\
\hline Breaker/ Ring & --- & --- & --- \\
\hline
\end{tabular}

Source: Aziz Pipes Limited

Appendix-II: Plastic Table, Doors \& Windows and its Different Title of Sections

\begin{tabular}{|c|c|c|c|c|}
\hline Usage & Title of Sections & $\begin{array}{c}\text { Speed } \\
\mathbf{M} / \mathbf{m i n}\end{array}$ & $\begin{array}{c}\text { Output } \\
\text { Kg/hr. }\end{array}$ & $\begin{array}{c}\text { Weight } \\
\text { Gm/m }\end{array}$ \\
\hline Table & Partition Mullion & 1.3 & 78.6 & 1008 \\
\hline Door & Partition Frame & 1.3 & 68.9 & 883 \\
\hline Door & Sliding Frame & 1.3 & 78.9 & 1011 \\
\hline Window & Sliding Glass Bead & 2.5 & 21.7 & 145 \\
\hline Window & Sliding Coupling & 1 & 20.6 & 343 \\
\hline Window & Sliding Interlock & 1.5 & 17.0 & 189 \\
\hline Window & Partition Glass Bead & 2.5 & 29.6 & 197 \\
\hline Door & Sliding Sash & 1.4 & 68.7 & 818 \\
\hline Door & Door Frame/ Sash & 1.5 & 65.0 & 1800 \\
\hline
\end{tabular}


Marketing System of Plastic Door in Bangladesh: A Study on Aziz Pipes Limited Md. Zahir Uddin Arif, Mohammad Amzad Hossain Sarker and Mir Semon Haider

Appendix-III: Product Specification of Aziz Pipes Limited

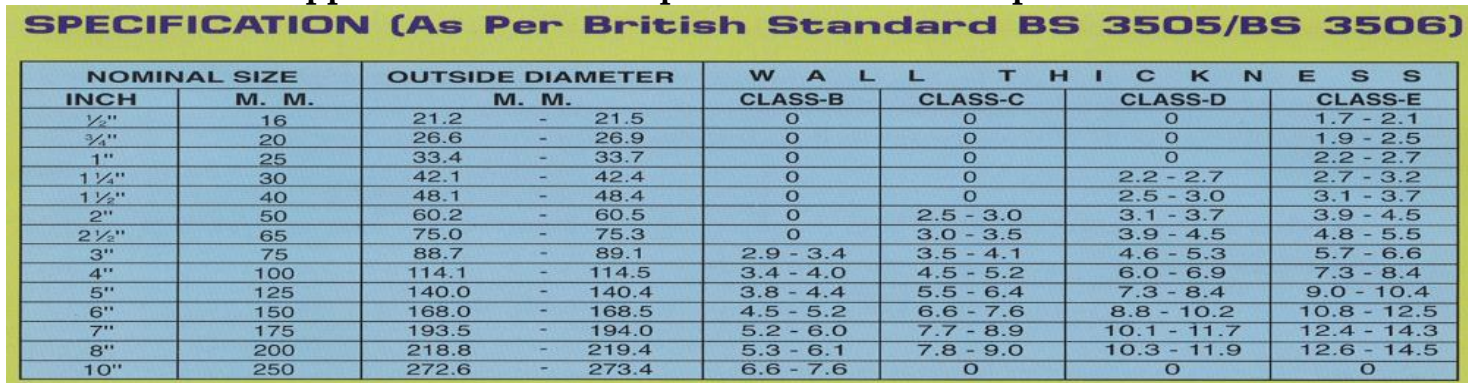

Source: Aziz Pipes Limited

(http://www.azizpipes.com/index.php?option=com_content\&view=article\&id=41\&Itemid=90)

\section{Appendix-IV: Dimensions of U-PVC Pipes of Aziz Pipes Limited}

\begin{tabular}{|c|c|c|c|c|c|c|c|c|c|c|c|c|c|c|c|}
\hline \multicolumn{2}{|c|}{ Size } & \multicolumn{2}{|c|}{ Nominal Outside Diameter } & \multicolumn{2}{|c|}{ Class - 1} & \multicolumn{2}{|c|}{ Class-2 } & \multicolumn{2}{|c|}{ Class -3} & \multicolumn{2}{|c|}{ Class - 4} & \multicolumn{2}{|c|}{ Class - 5} & \multicolumn{2}{|c|}{ Class -6} \\
\hline Ins. & MM & Min & Max & Min & Max & Min & $\operatorname{Max}$ & Min & $\operatorname{Max}$ & Min & Max & $\operatorname{Min}$ & $\operatorname{Max}$ & Min & Max \\
\hline 1.5 & $40 \mathrm{~mm}$ & 40.0 & 40.30 & - & . & the & (7) & 1.40 & 1.80 & 1.80 & 220 & 2.20 & 2.70 & 2.80 & 3.30 \\
\hline (2) & $50 \mathrm{~mm}$ & 50.0 & 50,30 & D & -8 & the & tif & 1.70 & 2.10 & 2.30 & 2.80 & 2.80 & 3.30 & 3.40 & 4.00 \\
\hline 3 & $75 \mathrm{~mm}$ & 75.0 & 75,30 & D. & - & 1.80 & 2.80 & 3.10 & 3.70 & 4.0 & 4.60 & 5.00 & 5.70 & 6.10 & 7,10 \\
\hline $4^{\prime \prime}$ & $100 \mathrm{~mm}$ & 1100 & 110.40 & 1.60 & 2.00 & 2.50 & 3.00 & 3.70 & 4.30 & 4,90 & 5.60 & 6.10 & 7.10 & 7.50 & 8.70 \\
\hline 5" & $125 \mathrm{~mm}$ & 125.0 & 125.40 & 1.80 & 2.20 & 2.90 & 3.40 & 4.30 & 5.00 & 5.60 & 6.40 & 6.90 & 8.00 & 8,50 & 9.80 \\
\hline 6? & $150 \mathrm{~mm}$ & 160.0 & 160.50 & 2.30 & 280 & 3.80 & 4.30 & 5.40 & 6.20 & 7.20 & 8.30 & 8.80 & 10,20 & 10.90 & 12.60 \\
\hline $8^{\prime \prime}$ & $200 \mathrm{~mm}$ & 200,0 & 200.60 & 2.90 & 3.40 & 4.60 & 5.30 & 6.80 & 7.90 & 8.90 & 10.30 & 11.00 & 12.70 & 13.60 & 15.70 \\
\hline $10^{\prime \prime}$ & $250 \mathrm{~mm}$ & 2500 & 250.80 & 3.60 & 4.20 & 5.70 & 6.50 & 8.50 & 9.80 & 11.20 & 12.90 & 13.80 & 15.90 & 17,00 & 19.60 \\
\hline
\end{tabular}

Source: Aziz Pipes Limited

(http:/ / www.azizpipes.com/index.php?option=com_content\&view=article\&id=41\&Itemid=90) 